\title{
The determinants of conversion rates in SME e-commerce websites
}

\begin{abstract}
Web retailers invest significant resources to improve the proportion of website visitors that make a purchase, also known as the conversion rate. Improving this rate is particularly important to SMEs that have traditionally lagged behind larger firms as they have found it difficult to justify the significant investment involved in website development against the historical low returns associated with an online sales channel. Identifying methods that increase conversion rates reduces these perceived barriers and increases effective SME participation in the growing e-commerce sector. This paper uses 1184 observations from 6 SME websites to identify and analyse the factors, or combination of factors, that improve conversion rates. This is achieved through a process of exploratory regression analysis to select the most relevant determinants and Qualitative Comparative Analysis (QCA) to offer more 'fine-grained' detail on the conditions where conversion rates improve. Our findings suggest that a key factor that improves the conversion rate is a strategy that focuses upon either quality or promotion and avoids mixing such attributes within the web site offer.
\end{abstract}

\section{Keywords}

conversion rate; web retailing; SMEs; fQCA 


\section{Introduction}

An increasing number of firms in the retail sector have developed digital channels to support sales and marketing strategies (Kaufmann et al., 2012) and online retailers have become gradually more successful in increasing traffic to their websites. As a consequence, projections show that retail ecommerce sales will increase from \$1548 trillion in 2015 to \$4.058 trillion in 2020, making up 14.6\% of total retail spending (Smart Insights, 2017). To manage this evolution, web retailers need to invest significant resources, to enhance functionality, increase visitor numbers and convert more such visits into purchases (Ayanso and Yoogalingam, 2009). However in the SME sector where resources and expertise are limited, this activity must be accomplished with considerable efficiency and cost effectiveness (Grandon et al., 2011; Cronin-Gilmore, 2012). In the past, concerns about costs and the strategic relevance of online sales has limited SME engagement in e-commerce activity (Bharadwaj and Soni, 2007), but, as on-line retail sales have grown, such concerns are no longer valid and internet/web-based technologies are widely recognized as an important element of effective sales and marketing (Bell and Loane 2010; Jeansson et al., 2017). In Italy the fashion industry provides a good example of this change. Defined as a market where apparel, bags, shoesand related accessories are sold (Christopher et al., 2004), the Italian fashion market in 2016 has an approximate value of 90 billion euros and unlike general industry trends has exhibited positive growth rates in the recent past (source: Mediobanca Study Office) 1.2. The SME sector accounts for more than half of this market value. It is important to recognise that the key factors that underpin this positive performance are increases in exports (+ 5.9\%) and online sales (tripled from $€ 5$ million in 2007 to $€ 15$ million in 2015 (source: Il sole 24 ore) ${ }^{3}$. Changes of this nature in the business environment have been recognised by SMEs and the sector is developing strategies to overcome barriers and exploit this opportunity.

These barriers, most often, refer to the limited skills and resource available to SMEs that discourage the adoption of e-commerce initiatives but also refer to the perceived difficulties in creating online reputation once resources have been committed (Kim et al., 2013). Consequently, SME e-commerce investments have been cautious and focused more on supporting communication strategies and developing business intelligence (Stockdale and Standing, 2006). The development of websites for transactional purposes carries more risk as it requires considerably more investment (McDowell et al., 2016) and if conversion rates, defined as the number of visitors who make a purchase directly

\footnotetext{
${ }^{3}$ http://www.ilsole24ore.com/

${ }^{3}$ http://www.ilsole24ore.com/

${ }^{3}$ http://www.ilsole24ore.com/
} 
from a website as a percentage of total visitors (Ayanso and Yoogalingam, 2009; Viglia 2014), are low such investment is difficult to justify.

To avoid up-front investment costs, SMEs often turn to the opportunities offered by e-commerce portals such as Amazon, Zalando or eBay. Such platforms have a larger internet footprint and can put SMEs in touch with significantly more customers but whether the benefits outweigh the costs is a moot point (Ritala et al., 2014). Independent firms that use established third party platforms to seek a foothold in the digital marketplace find themselves in a highly competitive and transparent environment. These markets are subject to commission on any sales completed and the platform controls the customer data making it difficult for small businesses to create consumer loyalty. Mauri (2003) has previously noted the difficulties that SMEs face to create loyalty in traditional retail and issues of data ownership can only amplify such issues in the digital market place. On a more qualitative note, industry analysts have expressed concern about the appropriateness of third party platforms for high end, luxury products, arguing that the front-end experience is not currently optimised for merchandising emotional products as their association on discounting often has a negative effect on those looking for luxury brands (Joy et al., 2014). Overall, the economies of scope and scale offered by third party platforms are often less beneficial to resource strapped SMEs that are competing on differentiation and product attribute. The alternative for an SME is to independently develop their own e-commerce website however, as Thimm et al. (2016) identify, only a minor portion of SMEs that invest in e-commerce functionality actually grow. This had led writers to argue that conversion rate management is a key factor in the digital technology adoption process of SMEs (Jia et al., 2017). We therefore suggest that any improvements in our understanding of the factors that enhance website conversion rates would be of considerable value to SMEs and the wider industry.

Despite the importance of conversion rates to sales and marketing strategies, research on understanding and analyzing the concept is limited (Ayanso and Yoogalingam, 2009). Previous studies have, in the main, focused upon enhancing our knowledge of online consumer behaviour, assuming that the intention to purchase is a strong predictor of actual consumption (Moe and Fader, 2004; Sismeiro and Bucklin, 2004; Hausman and Siekpe, 2009; Van Slyke et al., 2009; LorenzoRomero et al., 2014). Alternatively, work has considered the impact that improvements in search engine optimization techniques (Drèze and Zufryden, 2004; Ghose and Yang, 2009), or social media (Xiang and Gretzel, 2010) can have upon firm sales. This paper focuses directly upon conversion rates and seeks to identify factors that exhibit a positive influence upon a customer's decision to purchase once they have accessed the website. Following previous work (Ayanso and Yoogalingam, 2009), this study seeks to understand, through linear and equifinality relationships, 
the factors that underpin conversion rates by analyzing data from six different e-commerce websites in the fashion retail sector. The findings suggest that, for SMEs in this sector, improvements in conversion rates are possible, either by focusing on quality factors, or, paradoxically, by focusing exclusively upon promotional factors, such as discounted prices and free shipping.

\section{Theoretical background and research hypotheses}

The decision to adopt a website for commercial transactions is a salient for SMEs, given their budget constraints. As the Internet has developed so have the objectives and quality associated with company websites. In the early stages the focus was upon the dissemination of information and the provision of business intelligence (Daniel et al., 2002). These objectives placed the emphasis on increasing the amount of traffic to the website and success was measured by the number of unique visitors. Search engine optimization was integral to this process (Ayanso and Yoogalingam, 2009) but, as the online market has matured, websites have switched from a provider of information to a valuable sales channel and the emphasis moved from web traffic to the conversion of such traffic into sales (Drew, 2003; Jelassi and Leenen, 2003). The extant literature has followed this development with early work studying the technical requirements for site quality (Yoo and Donthu, 2001; Kim and Stoel, 2004) or focusing upon how customers are attracted to the website (Aladwani and Palvia, 2002; Parasaruman et al, 2005). Generalizing, Nguyen et al. (2016) argued that previous studies focused mainly on the use of marketing tools to improve consumer service levels, but that currently there exists a paucity of research conducted on the use of consumer service instruments to steer consumer behaviour and specifically to manage the conversion rate and consequently sales.

As websites evolved into sales channels limited research has investigated the factors that positively influenced the intention to purchase. Examples of this type of work include website visits (Moe and Fader, 2004), browsing experience and navigational behaviour (Sismeiro and Bucklin, 2004), web design and language (Hausman and Siekpe, 2009 and website aesthetics and length of exposure (Lorenzo-Romero et al., 2014). While this is not an exhaustive list, it highlights the focus of previous literatures on the intention to purchase and not on the actual sale, with the implied strong assumption that any increase in purchase intention will lead to higher conversion rates.

Examining conversion rates in the wider context it has been well documented that traditional retail finds it hard to encourage people to purchase once they are in store, for example, Söderlund et al. (2014) suggest that $54 \%$ of visitors leave a retail outlet without making a purchase. While this of concern to high-street retailers, the conversion rate of ecommerce websites (2\%-4\%) is significantly lower (Holzwarth et al., 2006; Sohrabi et al., 2012). In high-street retail commonly accepted explanations are that many customers, searching for a particular kind of product, visit several stores 
before buying or that shopping is simply a recreational activity (Gensler et al., 2017). These phenomena are particularly relevant in relation to e-commerce websites where the ease and speed with which users can move between websites is often seamless cutting the time and costs required to compare products encouraging such behaviour (Frost et al., 2010). However, historically ecommerce also generates issues that relate to trust within the transaction process, with customers concerned about the safety of personal information, credit card data and product authenticity (McCole et al., 2010; Kim and Peterson, 2017). In such circumstances consumers may use the website as a showroom, but purchase the goods from a high street store (Bonifield et al. 2010; Brynjolfsson et al., 2013). Although evidence suggests that consumer trust in online retail has significantly increased (European Commission, 2017), the use of a website just consultation webrooming (Flavian et al., 2016) - would significantly impact SMEs that have limited, or no, offline presence.

However, despite the perceived value in understanding the factors that improve conversion rates, there is limited literature that focuses upon the concept. According to Silverstein and Fiske, (2003) increasingly wide income disparities, higher levels of education and other cultural ideas of the socalled "good life" have given rise to a new group of consumers interested in a new category of products and services, luxury products. These products represent desirable objects that are consumed primarily for an affective and sensory experience of aesthetic or sensual pleasure, fantasy, and fun. Furthermore, even when luxury products address basic necessities, they evoke and engage consumers' emotions while feeding their aspirations for a better life (Silverstein and Fiske, 2003). The relative high price of luxury products, coupled with a greater perception of uncertainty regarding the authenticity and quality of the product being offered, increases the complexity of the consumer decision making process (Wolfinbarger and Gilly, 2003; Grewal et al, 2004), negatively impacting upon luxury product conversion rates compared with non-branded goods (Di Fatta et al., 2016).

Table 1 provides an overview of the most relevant factors which are explored in more detail in next section,

Table 1: Critical Factors affecting Purchase Intention and Conversion Rate 


\begin{tabular}{|c|c|l|}
\hline Critical Factor & $\begin{array}{l}\text { Purchase Intention } \\
\text { /Conversion Rate }\end{array}$ & \multicolumn{1}{|c|}{ Author(s) } \\
\hline \multirow{2}{*}{ Free shipping } & CR & $\begin{array}{l}\text { Zhu and Zhang (2010); Simoni (2011); } \\
\text { Bower and Maxham (2012); Koukova } \\
\text { (2012); Di Fatta et al., (2016) }\end{array}$ \\
\hline \multirow{2}{*}{ Free return } & CR & $\begin{array}{l}\text { Park and Lennon (2009); Pei et al (2014); } \\
\text { Petersen and Kumar (2015); Di Fatta et al., } \\
\text { (2016) }\end{array}$ \\
\hline \multirow{2}{*}{ Discount policy } & PI & $\begin{array}{l}\text { Udo and Marquis (2002); Park et al., } \\
\text { (2012); Ostapenko (2013); }\end{array}$ \\
\cline { 2 - 3 } & CR & $\begin{array}{l}\text { Zhu and Zhang (2010); Becerril-Arreola et } \\
\text { al., (2014); Di Fatta et al (2016) }\end{array}$ \\
\hline Season & CR & $\begin{array}{l}\text { Jackson (2007); Hernandez (2010); } \\
\text { Peinkofer et al. (2015) }\end{array}$ \\
\hline \multirow{2}{*}{ Speed of load } & PI & Selvidge (1999); Ladhari (2010). \\
\cline { 2 - 3 } Brand vs No-Brand & CR & $\begin{array}{l}\text { Plaza (2011); Akamai (2017) } \\
\text { Balabanis (2016) }\end{array}$ \\
\hline
\end{tabular}

\subsection{Promotional Factors}

Customers do not accept retailers charging higher prices online than offline and vice versa (Fassnacht and Unterhuber, 2016); however, when the product cannot be consumed online, items purchased have to undergo a shipping cost. These costs can either be absorbed by the retailer (free shipping for the customer) or be paid by the customer (Zhu and Zhang, 2010). A number of strategies exist between these two extremes, for example free shipping when the customer buys products that have a total price beyond an identified threshold, or free shipping only for registered users (Koukova et al., 2012). Di Fatta et al (2016) found that free shipping is an attractive factor for e-commerce websites, i.e., if retailers provide free shipping, the buyer will feel a higher level of customer satisfaction. Based on these arguments we put forward,

\section{H1: Free shipping has a positive impact on conversion rates}

Purchasing online is an uncertain process (Kirmani and Rao, 2000) and when the product, for whatever reason, does not meet expectations, customers want to be in a position to return it to the 
online retailer (Petersen and Kumar, 2015). While this issue is covered under consumer protection legislation, the online retailer could facilitate the return of goods by paying for return shipment. This is in line with previous work (Simoni, 2011), which suggests a structural rethinking of the logistic function in order to satisfy the specific needs of e-commerce purchasers. Some scholars argue that this form of promotion is particularly effective for a limited time period (Park and Lennon, 2009). While the benefit of such actions would appear axiomatic, another stream of literature suggests that this factor has little influence on a consumer's decision to complete an online transaction (Bower and Maxham, 2012). Pei et al. (2014) analyzing consumers’ perceived fairness of return policy and purchase intention, showed that an e-tailer's return depth has a positive influence on the perceived fairness of the return policy and purchase intention, but this relation is significantly moderated by the retailer's reputation.

In order to address this ambiguity in the literature, this article tests whether a return service, fully paid for by the online retailer, has any impact upon conversion rates. We posit that, given consumers' reduced uncertainty and costs, free returns significantly influence the conversion rate.

\section{H2: Free return service has a positive impact on conversion rates}

It has been argued that pricing policy and discounts have a clear and positive impact upon online customer satisfaction (Udo and Marquis, 2002), positively influencing the intention to purchase (Park et al., 2012; Ostapenko, 2013). Other work (Zhu and Zhang, 2010; Di Fatta et al. 2016) also identify discounts as an important factor that users perceive as attractive when browsing a website. Becerril-Arreola et al., (2014) have argued that, from the seller's point of view, a reduction of the profit margin due to discount policy does not significantly affect the standard deviation of consumers' order sizes (in other words, purchase amounts), but significantly increases the average order size. Taking these findings a step further, this research investigates what specific impact discount has upon the decision to complete an online transaction with an e-commerce trader. As a consequence of one or all of these factors, the general expectation is that:

\section{H3: Discount policies positively affect conversion rates}

The presence of discounts and promotions often coincide with particular time periods in the year (Hernandez et al., 2010). Seasonality, therefore, should be considered when evaluating the impact discounts could have upon conversion rates. Previous studies have normally distinguished between two segments, the regular period and the sales period (Jackson, 2007; Viglia and Abrate, 2017). The 
origin of this distinction refers to the time at the end of each season (the so-called sales period or sales season) when retailers discount their products in order to minimise surplus merchandise (Zhu and Zhang, 2010). Setting discounted prices near the end of the season (for clearing retail inventories) is very difficult because markdowns enacted in this period have a lower impact on customer intentions to purchase. During this period consumers expect an increasing trend of discounts (usually $10-30 \%$ in the first two weeks, $30-50 \%$ in the third and fourth week, over 50\% for the last inventories), thus the effectiveness of discounts in the final part of the sales period tends to be minor (Zhu and Zhang, 2010). Nevertheless, price promotions are still extensively used to attract consumers in an online retail environment where consumer switching costs are low (Peinkofer et al., 2015). While we remain agnostic on the sign of the direction, we portray that

\section{H4: The sale season affects conversion rates}

\subsection{Quality Factors}

Attributes referring to quality are the second category of factors identified from the literature as affecting conversion rates. Quality refers both to the actual quality of the purchasing experience (service process) and the quality of the products being purchased (outcome). In what follows we expand on this two sub-categories.

In the first category, a key attribute is the speed at which the webpage loads and refreshes; Ladhari (2010) argues this underpins the perception of ease of use for the consumer and determines their satisfaction in the use of a website. This is supported by earlier research by Selvidge (1999); his experimental results showed the greater the delay in waiting for a web page to load the more significant were the observed user frustrations often leading to a decision to quit the page. In particular, marked behavioural differences were observed where users had waited longer than 30 seconds. More recently, the assessment of how fast a web page loads has been identified using Google Analytics “speed of load” scores; a synthetic indicator ranging from 0 to 100, with the latter being the optimal load speed. It is suggested (Plaza 2011) that any speed lower than 50 creates a sense of disappointment and frustration among users.

Akamai (2017) has shown that a 100-millisecond delay in website load time can hurt conversion rates by 7 percent. Accepting that the speed at which a website loads is a key quality indicator to users, this article investigates the simultaneous effect of speed of load combined with other variables influencing conversion rate.

H5: Load speed positively affects conversion rates 
The second category refers to the actual quality of the products being sold. In evaluating the factors that influence conversion rates it is useful to distinguish between luxury and mainstream fashion ecommerce websites (Duffy, 2005; Park et al, 2012).

Previous research (Srinivasan et al., 2002) posits that branded products are associated with a higher level of revenues. While luxury websites are closely associated with the brands that they sell, mainstream websites focus, more often, on relatively unknown brands or "non-branded" products (Pozhariev et al., 2015).

This paper makes the distinction between luxury and mainstream websites and uses the "Forbes' top 100 brand list 2017” for the fashion industry to make this distinction (see Wolfinbarger and Gilly, 2003; Grewal et al., 2004; Bilgihan and Bujisic, 2015; Beuckels and Hudders, 2016). We therefore make the assumption that luxury websites specialize in luxury brands and the majority of their online catalogue is composed of branded products.

In terms of monetary promotions this distinction is important, as previous literature about online discount (Chandon et al., 2000; Kim et al., 2007; Ostapenko, 2013) indicates that monetary promotions can only be effective on luxury websites where the so-called "flash sales" are employed, thus constraining promotional prices (e.g. only the first ten products/services purchased) to maintain exclusivity. Supposing that luxury and mainstream products have differential impacts on conversion rate, it is therefore suggested that discount policies are most effective on mainstream websites.

In addition, Bilgihan and Bujisic (2015) have recently found that web features have a differential impact on sales from the websites of luxury or mainstream product, and that the consumers of luxury products are more demanding when it comes to overall website quality and, in particular, load speed. With this in mind, this paper proposes the following hypotheses:

H6: Luxury and mainstream products have a differential impact on conversion rates

H6a: Discounts positively influence the conversion rates of mainstream products

H6b: Load speed positively influence the conversion rates of luxury products

Figure 1 shows the proposed conceptual framework and summarizes how promotional factors (free shipping, free return, discount policy and seasonality) are related to actions taken in certain periods; quality factors, instead, refer to the technical features of the website, (such as speed of load) and, on the other hand, commercial features of the product (specifically whether the products sold are branded). 
Stemming from linear relationships, the theoretical background proposes to explore some specific combinations of promotional and quality factors in determining conversion rates.

Figure 1. Conceptual Framework

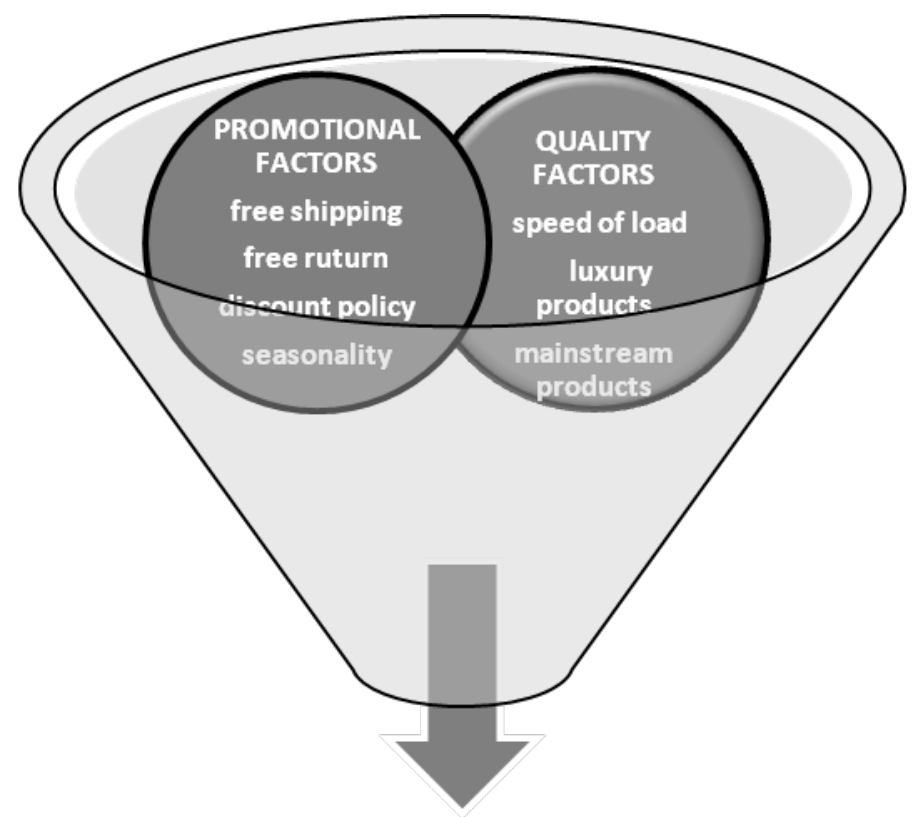

E-commerce Conversion Rate

\section{Methods and results}

\subsection{Sample and data collection}

Employing the Christopher et al. (2004) definition of the fashion industry, data were collected from six different SMEs e-commerce websites registered in the Italian market that sell apparel, bags, shoes and related accessories. Three of the six websites were devoted to sale of luxury products as per the Forbes 2017 list and the remaining three were concentrated upon the sale of mainstream products. Given the sensitivity of some financial output measures, retailers did not consent to provide publicly their identity; however, they are all established businesses, present in the market since the nineties, and they all operate in the Bags/Accessories/Apparel and Shoes sector with an average unit price of between 50 and 200 euros $^{4}$.

The following data (which will be explained in more detail in the next sections) were retrieved, number of daily visits to the website, number of orders placed, daily average webpage speed of

\footnotetext{
${ }^{4}$ The detailed anonymized dataset is available upon request to the first author.
} 
load, season, free shipping and/or free return options. It is important to note that discounts, free shipping and free returns were manipulated randomly across days within each website and experimental variation occurred on a day-to-day basis, but keeping the original unbalanced distribution (e.g., many more no free returns day than free returns day). In other words, in order to be able to identify causal effects, we have agreed with the 6 SMEs retailers to include/exclude these promotional levers across days.

The total collection period covers six months, from the $1^{\text {st }}$ of January 2016 to the $30^{\text {th }}$ of June 2016. The dataset consists of 1184 daily observations from the six websites, enabling an analysis of a large period that covers both regular and sales seasons.

Building on these data and following previous literature (Ayanso and Yoogalingam, 2009), this article identifies the conversion rate (the ratio between daily online purchases and website visitors) as the dependent variable. Thus, the paper considers two groups of independent variables, promotional and quality factors. The first group includes free shipping (i.e., when shipment is free for the purchaser), free returns (i.e., when returning the purchased goods does not incur in additional cost), discounted price (promotional sales with respect to the listed price) and season (regular or sales period). The second investigates the quality of the website, using the page load speed as a proxy (based on the Google Analytics parameter range from 0 to 100) and the type of product (luxury or mainstream websites). Finally, as a control variable, the study also includes the day of the week where the online visit took place. In order to summarize the variables available in the dataset, descriptive statistics are reported in Table 2.

Table 2. Descriptive statistics $(n=1184)$

\begin{tabular}{llcc} 
Type of variable & Variable & Average & SD \\
\hline Dependent variable & Conversion Rate (\%) & 6.84 & 1.03 \\
& & & \\
\hline Independent variables & Free shipping (0 no -1 yes) & 0.59 & 0.49 \\
& Free returns (0 no -1 yes) & 0.05 & 0.22 \\
& Discounts & 0.13 & 0.20 \\
& Season (0 regular; 1 sales) & 0.40 & 0.49 \\
\cline { 2 - 4 } & Speed of load (0-100) & 63.10 & 9.79 \\
& Luxury websites (0 non-brand & 0.54 & 0.50 \\
\hline
\end{tabular}


products ; 1 branded products)

\begin{tabular}{lll}
\hline Week ( 0 = Saturday \& Sunday - & 0.70 & 0.45 \\
$1=$ weekdays, Monday to Friday) & &
\end{tabular}

\subsection{Regression analysis}

An OLS regression with step-wise procedure (Bendel and Afifi, 1977) tests the impact of the independent variables on conversion rates. As the data involves multiple observations over time that are nested within the six retailers, we have clustered standard errors to correct for the correlations among the data from the same source.

The five significant variables are free shipping, discounts, season, load speed, and luxury.

Table 3. OLS regression

\begin{tabular}{|c|c|c|}
\hline & Model 1 & Model 2 \\
\hline VARIABLES & Conversion rate & Conversion Rate \\
\hline Free shipping & $\begin{array}{c}-0.379 * * * \\
(0,042)\end{array}$ & $\begin{array}{c}-0.366^{* * *} \\
(0,042)\end{array}$ \\
\hline Free returns & $\begin{array}{c}0.134 \\
(0,084)\end{array}$ & \\
\hline Discounts & $\begin{array}{c}3.911^{* * *} \\
(0,121)\end{array}$ & $\begin{array}{c}3.913 * * * \\
(0,121)\end{array}$ \\
\hline Season & $\begin{array}{c}0.185^{* * *} \\
(0,047)\end{array}$ & $\begin{array}{c}0.178 * * * \\
(0,047)\end{array}$ \\
\hline Speed of load & $\begin{array}{c}0.0262^{* *} \\
(0,013)\end{array}$ & $\begin{array}{c}0.0266^{* *} \\
(0,013)\end{array}$ \\
\hline Luxury & $\begin{array}{c}0.370 * * * \\
(0,039)\end{array}$ & $\begin{array}{c}0.374^{* * *} \\
(0,039)\end{array}$ \\
\hline Week & $\begin{array}{c}0,017 \\
(0,040)\end{array}$ & \\
\hline Constant & $\begin{array}{c}4.594 * * * \\
(0,786)\end{array}$ & $\begin{array}{c}4.581^{* * *} \\
(0,786) \\
\end{array}$ \\
\hline Observations & 1.184 & 1.184 \\
\hline$R$-squared & 0,647 & 0,646 \\
\hline$M d A P E$ & 7.34 & 7.36 \\
\hline $\begin{array}{r}\text { Star } \\
P \text { value. }\end{array}$ & $\begin{array}{l}d \text { errors in paren } \\
p<0.01, * * p<0\end{array}$ & $\begin{array}{l}\text { eses } \\
* p<0.1\end{array}$ \\
\hline
\end{tabular}

To test the predictive accuracy of the different models the paper shows goodness of fit measures based on the R-square and the median error. Specifically, Table 3 provides the R-square along with 
Median Absolute Percentage Error (MdAPE). The models present a fairly good explanatory power, with a minimal loss of accuracy in Model 2. Apart from free returns and the day of the week that the purchase took place, all the other variables appear to influence conversion rate. However, the regression approach only tests for the effects of the individual independent variables on conversion rate (the outcome variable). The possible impact any combination of factors have upon determining output (conversion rate) as identified in the theoretical underpinning remains unclear and, to test for this effect, a Qualitative Comparative Analysis (QCA) is undertaken to complement the regression analysis. The technique offers specific insights on all the combinations of promotional and quality factors that generate conversion rates, offering more flexibility than regressions with interaction effects.

\subsection{Qualitative Comparative Analysis}

Qualitative comparative analysis (QCA) identifies combinations of causal conditions that can lead to the outcome of interest. This is of particular value in this context, as the favourable conditions that lead to conversion rates tend to be different between luxury and non-branded products (Bilgihan and Bujisic, 2015). Additionally, as the recipe of these conjoint elements in the fashion context has not been investigated yet, equifinality conditions might be more appropriate than linear relationships to explore the interplay among the different factors (Ordanini et al., 2013),

\subsubsection{QCA findings}

QCA performs a systematic cross-case analysis that models relations among variables in terms of set membership and identifies configurations that reflect the necessary and sufficient conditions for an outcome of interest. QCA occurs in four steps. The first identifies all the combinations of the attributes that influence conversion rate: free shipping, discounts, season, speed of load, and category (luxury vs. mainstream). Because some independent variables are not dichotomous, the second step employs a fuzzy-set calibration approach to model the degree to which different cases belong to a set, ranging from 0 to 1 , including intermediate membership levels (Ragin, 2000). By applying Boolean algebra rules, it is then possible to build membership scores for configuration of attributes, in which each attribute is either present or absent. The next step requires the identification of attribute configurations that can act as sufficient conditions for conversion rates. For a configuration to be considered sufficient, the consistency measure should exceed a minimum threshold of 0.75 (Woodside, 2014). In the fuzzy sets, the assessment of consistency represents the sum of the membership scores in the causal set that take to the expected outcome (i.e., conversion rate) divided by the sum of all the membership scores that pertain to that causal set. The final step is 
to eliminate any redundant attributes from the sufficient configurations. An attribute is redundant when its presence or absence does not affect the outcome. For each reduced sufficient configuration, a coverage measure reflects the share of consistent membership as a portion of total membership in the outcome set. Table 4 presents the results from the QCA conducted using the STATA fuzzy package (Longest and Vaisey, 2008).

Table 4. QCA results

\begin{tabular}{ccccc} 
Group & Coverage Set & Raw Coverage & Unique Coverage & Solution Consistency \\
\hline (A1) & $\mathrm{f}^{*} \mathrm{D}^{*} \mathrm{~S} * \mathrm{~h}$ & 0,47 & 0,47 & 0,976 \\
(A2) & $\mathrm{F}^{*} \mathrm{D} * \mathrm{~L}$ & 0,29 & 0,061 & 0,978 \\
(A3) & $\mathrm{F}^{*} \mathrm{D} * \mathrm{~h}$ & 0,330 & 0,032 & 0,955 \\
(B1) & $\mathrm{F}^{*} \mathrm{~d}^{*} \mathrm{~S}^{*} \mathrm{~L} H$ & 0.014 & 0.014 & 0,915 \\
(B2) & $\mathrm{F}^{*} \mathrm{~s} \mathrm{~L}^{*} \mathrm{H}$ & 0,172 & 0,023 & 0,953 \\
\hline
\end{tabular}

Note: $F=$ free shipping $D=$ discounts $S=$ season $L=$ speed of load $H=$ luxury products

Lowercase = attribute absent, Uppercase $=$ attribute present

Total coverage $=0.474$

Solution Consistency $=0.949$

The rows clarify the configurations of attribute that are sufficient for inducing engagement behaviors, with consistency and coverage measures for each configuration and the whole solution; five configurations that can all stimulate cooperative behaviors emerge. All the selected configurations have significant consistency, much higher than the minimum required threshold. It is possible to identify the presence of two broad groups, labelled as A and B. Group A revolves around the impact of discounts (D) associated occasionally with the promotional season (S) and in most cases, with free shipping (F). For discounts associated with the promotional season (S), the solution $A 1$ (that is $f^{*} D^{*} S^{*} h$ ) shows the highest coverage value $(0.47)^{5}$. The relevance of the combination of variable season (S) and discount (D) is attributable to the so-called "seasonal shoppers” effect (Laudon et al., 2007), meaning that many users wait for this particular period within the season to take advantage of the favourable terms of trade. Analysing A2 and A3, when free shipping (F) and discount (D) are brought together, this combination is very effective in generating additional sales, and thus affecting conversion rates. Group B is identified as luxury ecommerce, characterized by the presence of luxury products $(\mathrm{H})$ in combination with load speed (L). This finding for e-commerce is consistent with the argument made by Chandon et al., (2000)

\footnotetext{
${ }^{5}$ The higher the coverage, the higher the consistent membership.
} 
who highlighted that, in stores, monetary promotions are less effective for luxury than mainstream products.

To assess the goodness of the QCA model, a fundamental issue concerns the variable calibration, which determines the class membership of cases. Although our calibration procedure was based on methodological guidelines in the QCA literature (Schneider and Wagemann 2010), and all the independent variables but the speed of load are dichotomous (0-1), we conducted additional checks to verify the robustness of our continuous outcomes across different calibration choices. Following Woodside (2012), we changed the threshold levels for the outcomes, originally being fuzzy score $=$ 0.95 for full membership, fuzzy score $=0.50$ for cross-over point and fuzzy score $=0.05$ for full non-membership. These three threshold values were re-set at $0.75,0.5$ and 0.25 and the results remained the same as those presented in Table 4, suggesting that the findings are quite stable and robust.

\section{Discussion and conclusion}

E-commerce has become an increasingly important conduit for all firms, but more significant for SMEs that have a limited geographical reach without access to the potential customer base that can be generated from the Internet. However, it is well known that the costs associated with establishing and running websites, and the skill sets required to fully exploit them negatively impact upon the take up rate of such technologies within the SME community (Daniel et al., 2002; Stockdale and Standing, 2006; Abou-Shouk et al., 2013). These issues are compounded by the uncertainty that surrounds the payback on such investments due to current low conversion rates and our limited understanding of how these rates could be improved. This paper seeks to address these issues by identifying factors that foster increased conversion rates and therefore promoting e-commerce to SMEs thinking of investing in such technologies and facilitating higher rates of conversion among SMEs that already exhibit such capability. Hence this article investigates how e-commerce websites are able to positively influence conversion rates through the careful management of two key dimensions, promotions and quality. As indicated previously this research focuses upon findings drawn from six firms within the fashion retail sector. This sector was selected as it is able to span both mainstream and luxury products, but also because it lends itself to the development of independent e-commerce websites.

Prior to starting this research we were aware that it was likely that most factors analysed would exhibit some impact on conversion rates. The regression analysis provides evidence of this but falls short to provide the specific fertile factor combinations that lead to conversion rates. To address this problem and provide a more fine-grained understanding the paper employs QCA analysis to 
investigate the potential impact of factor combinations and specifically the interplay between mainstream and luxury product offerings. Starting with promotions, our findings show that discounts and free shipping, working together, boost the conversion rate for e-commerce websites, supporting research hypotheses $\mathrm{H} 1$ and H3. It is also interesting to note that the individual effect of free shipping on the conversion rate is negative. One possible explanation is that the notion of free shipping, on its own, is often perceived by the customer as being incorporated into the price of the product increasing the final cost and, thus, negatively impacting on conversion rates. While this finding is consistent with previous studies about online sales (Burt and Spark, 2003; Park et al., 2012), the fuzzy analysis provides a more detailed perspective, highlighting that when free shipping is associated with luxury products this negative consumer perception is discarded and a positive effect on conversion rate is reported. Similarly, the simultaneous presence of discounts during the sale season also have a positive impact upon completion rates providing support to $\mathrm{H} 4$ and further support to H3. Surprisingly, our findings were not able to identify any relationship between the provision of a free return service and any increase in conversion rates. There are two competing explanations for this finding. First, the number of observations with this characteristic is relatively low (64, as can be retrieved from Table 4). Second, this factor may only be considered an advantage if the original purchase is, for whatever reason, not acceptable. In sum, H2 is not supported.

The empirical results also suggest that luxury and mainstream products have a differential impact on conversion rates (H6). In particular, the effect of promotional factors on the conversion rates for luxury products is lower than the one exhibited by mainstream products, supporting H6a. On a similar note, while speed of load is generally important to drive up conversion rates, for the combinations with luxury products speed of load is a sine-qua-non condition to boost conversion rates (H6b).

This research addresses a number of issues that have both theoretical and managerial implications. The results are particularly important for the establishment and exploitation of ecommerce websites by SMEs. Historically, SMEs have found that the payback from investments in ecommerce websites to be less than satisfactory and this has been a significant factor in other SMEs choosing not to undertake such investment. Theoretically, these findings constitute an important step forward in understanding the dynamics of conversion rate management in e-commerce websites; reducing the levels of uncertainty surrounding the investment decision and increasing the potential for revenue generation from existing websites. The identification of the promotional/quality subgroups is an explorative starting point for future studies in that this duality is an original step forward for conversion rate management consistent with previous studies in traditional retail (Babin et al., 1994), accuracy in forecast (Invernizzi et al. 2017) and storytelling (Pera and Viglia, 2016). In 
addition, the innovative use of QCA in the SME fashion landscape identifies a tool that can facilitate the examination of an array of complex factors associated with conversion rate improvements. This is an advancement on previous studies (ref) which have only considered the individual effect of certain variables on conversion rate optimization.

Practically, this is very relevant to the recent focus by governments in Europe to increase the participation of SMEs in digital technologies. These results help to inform and guide managers of SME e-commerce websites on the requisite characteristics that contribute to improved conversion rates, positively affecting revenues and providing better returns on such investments. While it is recognised that other barriers exist to digital participation, conversion rates provide evidence of successful participation in online retail reducing uncertainty, increasing confidence and influencing non-participating SMEs to develop their own e-commerce website. Therefore, understanding how the manipulation of factors can improve conversion rates helps to inform e-commerce website creation, reduce development costs, increase revenues and provide data to enable continued improvement.

This work is not without limitations. The first is related to the dataset, in that using daily fashion retail aggregated data potentially loses some information about individual transactions that cannot be tracked. Secondly, recalling that this paper focused on the funnel process (once a customer has accessed the e-commerce webpage), some antecedent factors affecting the amount of traffic to the website, such as search engine optimization (SEO) or website position in Google ranks, were not considered as they were beyond the scope of this research.

Future research might examine the impact that other website quality factors have on conversion rates, in particular the degree to which engaging with the website is an enjoyable experience, and the extent to which this impact is similar across industries. In addition, researchers may also wish to consider factors beyond promotions and quality, for example the role of social media in attracting and referring visitors to websites and influencing the decision to purchase. 


\section{Bibliography}

Abou-Shouk, M., Lim, W. M., \& Megicks, P. (2013). e-Commerce and small tourism businesses in developing countries: Drivers versus boundaries of adoption. Tourism Planning \& Development, 10(3), 249-266.

Aladwani A.M., Palvia P.C. (2002). Developing and validating an instrument for measuring user perceived web quality. Information \& Management. 39(2), 467-476.

Akamai Technologies, (2017). The State of Online Retail Performance (Report Spring 2017), https://www.soasta.com/wp-content/uploads/2017/04/State-of-Online-Retail-PerformanceSpring-2017.pdf retrieved in December 2017.

Ayanso, A., \& Yoogalingam, R. (2009). Profiling retail web site functionalities and conversion rates: A cluster analysis. International Journal of Electronic Commerce, 14(1), 79-114.

Babin, B. J., Darden, W. R., \& Griffin, M. (1994). Work and/or fun: measuring hedonic and utilitarian shopping value. Journal of Consumer Research, 20(4), 644-656.

Becerril-Arreola, R., Leng, M., \& Parlar, M. (2013). Online retailers’ promotional pricing, freeshipping threshold, and inventory decisions: A simulation-based analysis. European Journal of Operational Research, 230(2), 272-283.

Bell, J., \& Loane, S. (2010). 'New-wave'global firms: Web 2.0 and SME internationalisation. Journal of Marketing Management. 26(3-4), 213-229.

Bendel, R. B., \& Afifi, A. A. (1977). Comparison of stopping rules in forward "stepwise" regression. Journal of the American Statistical Association, 72(357), 46-53.

Beuckels, E., \& Hudders, L. (2016). An experimental study to investigate the impact of image interactivity on the perception of luxury in an online shopping context. Journal of Retailing and Consumer Services, 33, 135-142.

Bharadwaj, P. N., \& Soni, R. G. (2007). E-commerce usage and perception of e-commerce issues among small firms: Results and implications from an empirical study. Journal of Small Business Management, 45(4), 501-521.

Bilgihan, A., \& Bujisic, M. (2015). The effect of website features in online relationship marketing: A case of online hotel booking. Electronic Commerce Research and Applications, 14(4), 222232.

Bonifield, C., Cole, C., \& Schultz, R. L. (2010). Product returns on the Internet: A case of mixed signals?. Journal of Business Research, 63(9), 1058-1065.. 
Bower A. B. \& Maxham III J.G. (2012), Return shipping policies of online retailers: normative assumptions and the long-term consequences of fee and free returns, Journal of Marketing, 76 (5), 110-124.

Brynjolfsson, E., Hu, Y. J., \& Rahman, M. S. (2013). Competing in the age of omnichannel retailing. MIT sloan management Review, 54(4), 23.

Burt, S., \& Sparks, L. (2003). E-commerce and the retail process: a review. Journal of Retailing and Consumer Services, 10(5), 275-286.

Chandon, P., Wansink, B., \& Laurent, G. (2000). A benefit congruency framework of sales promotion effectiveness. Journal of Marketing, 64(4), 65-81.

Christopher, M., Lowson, R., \& Peck, H. (2004). Creating agile supply chains in the fashion industry. International Journal of Retail \& Distribution Management, 32(8), 367-376.

Cronin-Gilmore, J. (2012). Exploring marketing strategies in small businesses. Journal of Marketing Development and Competitiveness, 6(1), 96.

Daniel, E., Wilson, H., \& Myers, A. (2002). Adoption of E-Commerce by SMEs in the UK towards a stage model. International Small Business Journal, 20(3), 253-270.

Di Fatta, D., Musotto, R. \& Vesperi, W. (2016), Analyzing e-commerce websites: a qualiquantitative approach for the User Perceived Web Quality (UPWQ). International Journal of Marketing Studies, 8(6), 33-44.

Drew, S. (2003). Strategic uses of e-commerce by SMEs in the east of England. European Management Journal, 21(1), 79-88.

Drèze, X., \& Zufryden, F. (2004). Measurement of online visibility and its impact on Internet traffic. Journal of Interactive Marketing, 18(1), 20-37.

Duffy, D. L. (2005). Affiliate marketing and its impact on e-commerce. Journal of Consumer Marketing, 22(3), 161-163.

EMarketer (2014), Data Feed for August 30, 2017. Key stats you need to know about today. https://www.emarketer.com/Data-Feed-August-30-2017.

European Commission (2017) Consumer Conditions Scoreboard: Consumers at home in the Single Market Justice and Consumers Directorate Generalhttp://ec.europa.eu/newsroom/just/itemdetail.cfm?item_id=117250

Fassnacht, M., \& Unterhuber, S. (2016). Consumer response to online/offline price differentiation. Journal of Retailing and Consumer Services, 28, 137-148.

Flavián, C., Gurrea, R., \& Orús, C. (2016). Choice confidence in the webrooming purchase process: The impact of online positive reviews and the motivation to touch. Journal of Consumer Behaviour, 15(5), 459-476. 
Frost, D., Goode, S., \& Hart, D. (2010). Individualist and collectivist factors affecting online repurchase intentions. Internet Research, 20(1), 6-28.

Gensler, S., Neslin, S. A., \& Verhoef, P. C. (2017). The Showrooming Phenomenon: It's More than Just About Price. Journal of Interactive Marketing, 38, 29-43.

Ghose, A., \& Yang, S. (2009). An empirical analysis of search engine advertising: Sponsored search in electronic markets. Management Science, 55(10), 1605-1622.

Grandón, E. E., Nasco, S. A., \& Mykytyn, P. P. (2011). Comparing theories to explain e-commerce adoption. Journal of Business Research, 64(3), 292-298.

Grewal, D., Gopalkrishnan, R. I., \& Levy, M. (2004). Internet retailing: Enablers, limiters and marketing consequences. Journal of Business Research, 57(7), 703-713.

Hausman, A.V. and Siekpe, J.S. (2009), The effect of web interface features on consumer online purchase intentions, Journal of Business Research, 62(1), 5-13.

Hernández, B., Jiménez, J., \& Martín, M. J. (2010). Customer behavior in electronic commerce: The moderating effect of e-purchasing experience. Journal of Business Research, 63(9), 964971.

Holzwarth, M., Janiszewski, C., \& Neumann, M.M. (2006). The influence of avatars on online consumer shopping behavior. Journal of Marketing, 70(4), 19-36.

Houghton, K.A. and Winklhofer, H. (2004), The effect of website and e-commerce adoption on the relationship between SMEs and their export intermediaries, International Small Business Journal, 22(4), 369-388.

Invernizzi, A. C., Menozzi, A., Passarani, D. A., Patton, D., \& Viglia, G. (2017). Entrepreneurial overconfidence and its impact upon performance. International Small Business Journal, 35(6), 709-728.

Jackson, T. (2007). The process of trend development leading to a fashion season, in Fashion Marketing: contemporary issues, chapter 9, 168-187. Butterworth-Heinemann, imprint of Elsevier, Oxford (UK).

Jeansson, J., Nikou, S., Lundqvist, S., Marcusson, L., Sell, A., \& Walden, P. (2017). SMEs’ online channel expansion: value creating activities. Electronic Markets, 27(1), 49-66.

Jelassi, T., \& Leenen, S. (2003). An E-Commerce Sales Model for Manufacturing Companies: A Conceptual Framework and a European Example. European Management Journal, 21(1), 3847.

Jia, Q., Guo, Y., \& Barnes, S. J. (2017). Enterprise 2.0 post-adoption: Extending the information system continuance model based on the technology-Organization-environment framework. Computers in Human Behavior, 67(2), 95-105. 
Joy, A., Wang, J. J., Chan, T. S., Sherry, J. F., \& Cui, G. (2014). M (Art) worlds: consumer perceptions of how luxury brand stores become art institutions. Journal of Retailing, 90(3), 347-364.

Kaufmann, H.R., Loureiro, S.M.C., Basile, G. \& Vrontis G. (2012), The increasing dynamics between consumers, social groups and brands, Qualitative Market Research: An International Journal, 15(4), 404-419.

Kim, H. D., Lee, I., \& Lee, C. K. (2013). Building Web 2.0 enterprises: A study of small and medium enterprises in the United States. International Small Business Journal, 31(2), 156174.

Kim, J., Fiore, A. M., \& Lee, H. H. (2007). Influences of online store perception, shopping enjoyment, and shopping involvement on consumer patronage behavior towards an online retailer. Journal of retailing and Consumer Services, 14(2), 95-107.

Kim M. \& Stoel L. (2004). Apparel retailers: web site quality dimensions and satisfaction. Journal of Retailing and Consumer Services, 11(1), 109-117.

Kim, Y., \& Peterson, R. A. (2017). A Meta-analysis of Online Trust Relationships in Ecommerce. Journal of Interactive Marketing, 38(2), 44-54.

Kirmani, A., \& Rao, A. R. (2000). No pain, no gain: A critical review of the literature on signaling unobservable product quality. Journal of Marketing, 64(2), 66-79.

Koukova, N. T., Srivastava, J., \& Steul-Fischer, M. (2012). The effect of shipping fee structure on consumers' online evaluations and choice. Journal of the Academy of Marketing Science, 40(6), 759-770.

Ladhari, R. (2010). Developing e-service quality scales: A literature review. Journal of Retailing and Consumer Services, 17(6), 464-477.

Laudon, K. C., \& Traver, C. G. (2007). E-commerce. Pearson/Addison Wesley. Boston (USA).

Longest, K. C., \& Vaisey, S. (2008). fuzzy: A program for performing qualitative comparative analyses (QCA) in Stata. Stata Journal, 8(1), 79-94.

Lorenzo-Romero, C., Constantinides, E. and Alarcón-del-Amo, M.D.C. (2014), Web aesthetics effects on user decisions: impact of exposure length on website quality perceptions and buying intentions, Journal of Internet Commerce, 12(1), 76-105.

Mauri, C. (2003). Card loyalty. A new emerging issue in grocery retailing. Journal of Retailing and Consumer Services, 10(1), 13-25. 
McCole, P., Ramsey, E., \& Williams, J. (2010). Trust considerations on attitudes towards online purchasing: The moderating effect of privacy and security concerns. Journal of Business Research, 63(9), 1018-1024.

McDowell, W. C., Wilson, R. C., \& Kile, C. O. (2016). An examination of retail website design and conversion rate. Journal of Business Research. 69(11), 4837-4842.

Moe, W.W. and Fader, P.S. (2004), Dynamic conversion behavior at e-commerce sites, Management Science, 50(3), 326-335.

Nguyen, D. H., de Leeuw, S. and Dullaert, W. E.H. (2016), Consumer Behaviour and Order Fulfilment in Online Retailing: A Systematic Review. International Journal of Management Reviews. (online open access doi:10.1111/ijmr.12129)

Ordanini, A., Parasuraman, A., \& Rubera, G. (2013). When the recipe is more important than the ingredients a qualitative comparative analysis (QCA) of service innovation configurations. Journal of Service Research, 17(2), 134-149.

Ostapenko, N. (2013). Online discount luxury: In search of guilty customers. International Journal of Business and Social Research, 3(2), 60-68.

Otero, E. L., Gallego, P. A. M., \& Pratt, R. M. (2014). Click-and-Mortar SMEs: Attracting customers to your website. Business Horizons, 57(6), 729-736.

Parasuraman A., Zeithaml V.A., Malhotra A. (2005). E-S-QUAL.: a multiple-item scale for assessing electronic service quality. Journal of Service Research, 7(3), 213-34.

Park, E. J., Kim, E. Y., Funches, V. M., \& Foxx, W. (2012). Apparel product attributes, web browsing, and e-impulse buying on shopping websites. Journal of Business Research, 65(11), 1583-1589.

Pei, Z., Paswan, A., \& Yan, R. (2014). E-tailer' s return policy, consumer' s perception of return policy fairness and purchase intention. Journal of Retailing and Consumer Services, 21(3), 249-257.

Peinkofer, S. T., Esper, T. L., Smith, R. J., \& Williams, B. D. (2015). Assessing the impact of price promotions on consumer response to online stockouts. Journal of Business Logistics, 36(3), 260-272.

Pera, R., \& Viglia, G. (2016). Exploring how digital storytelling builds digital personal reputation. Psychology \& Marketing, 33(12), 1142-1150.

Petersen, J. A., \& Kumar, V. (2015). Perceived Risk, Product Returns, and Optimal Resource Allocation: Evidence from a Field Experiment. Journal of Marketing Research, 52(2), 268285. 
Plaza, B. (2011). Google Analytics for measuring website performance. Tourism Management, 32(3), 477-481.

Pozharliev, R., Verbeke, W. J., Van Strien, J. W., \& Bagozzi, R. P. (2015). Merely being with you increases my attention to luxury products: Using EEG to understand consumers' emotional experience with luxury branded products. Journal of Marketing Research, 52(4), 546-558.

Ragin, C. (2000). Fuzzy-set social science. University of Chicago Press. Chicago (USA).

Ritala, P., Golnam, A., \& Wegmann, A. (2014). Coopetition-based business models: The case of Amazon. com. Industrial Marketing Management, 43(2), 236-249.

Schneider, C. Q., \& Wagemann, C. (2010). Standards of good practice in qualitative comparative analysis (QCA) and fuzzy-sets. Comparative Sociology, 9(3), 397-418.

Selvidge, P. (1999). How long is too long to wait for a website to load. Usability News, 1(2), 1-3.

Smart Insights. (2017). Ecommerce growth statistics - UK and Worldwide. [online] Available at: http://www.smartinsights.com/digital-marketing-strategy/online-retail-sales-growth/ [Accessed 5 Sep. 2017].

Silverstein, M. J., \& Fiske, N. (2003). Luxury for the masses. Harvard business review, 81(4), 4857.

Simoni, C. (2011). L’impatto del commercio elettronico business-to-consumer sulla logistica distributiva, con particolare riferimento alla logistica dell'“ultimo miglio”. Sinergie Italian Journal of Management, 57(2), 151-175.

Sismeiro, C. and Bucklin, R.R. (2004), Modeling purchase behavior at an e-commerce Web site: a task completion approach, Journal of Marketing Research, 41(3), 306-323.

Söderlund, M., Berg, H., \& Ringbo, J. (2014). When the customer has left the store: An examination of the potential for satisfaction rub-off effects and purchase versus no purchase implications. Journal of Retailing and Consumer Services, 21(4), 529-536.

Sohrabi, B., Mahmoudian, P., \& Raessi, I. (2012). A framework for improving e-commerce websites' usability using a hybrid genetic algorithm and neural network system. Neural Computing and Applications, 21(5), 1017-1029.

Srinivasan, S. S., Anderson, R., \& Ponnavolu, K. (2002). Customer loyalty in e-commerce: an exploration of its antecedents and consequences. Journal of Retailing, 78(1), 41-50.

Stathopoulou, A., \& Balabanis, G. (2016). The effects of loyalty programs on customer satisfaction, trust, and loyalty toward high-and low-end fashion retailers. Journal of Business Research, 69(12), 5801-5808.

Stockdale, R., \& Standing, C. (2006). A classification model to support SME e-commerce adoption initiatives. Journal of Small Business and Enterprise Development, 13(3), 381-394. 
Thimm, H. H., Rasmussen, K. B., \& Gohout, W. (2016). Website quality and performance indicators including ratio numbers-A study of German and Danish SME companies. Journal of Business, 1(3), 22-36.

Udo, G. J. \& Marquis, G. P. (2002) Factors affecting e-commerce Web site effectiveness. The Journal of Computer Information Systems, 42(2), 10-16.

Van Slyke, C., Belanger, F. and Comunale, C.L. (2009), A behavioral beliefs model of trustworthiness in consumer-oriented e-commerce, Journal of Electronic Commerce in Organizations 7(2), 22-43.

Viglia, G. (2014). Pricing, Online Marketing Behavior, and Analytics. Springer. New York, USA.

Viglia, G., \& Abrate, G. (2017). When distinction does not pay off-Investigating the determinants of European agritourism prices. Journal of Business Research, 80, 45-52.

Wolfinbarger, M., \& Gilly, M. C. (2003). eTailQ: dimensionalizing, measuring and predicting etail quality. Journal of Retailing, 79(3), 183-198.

Woodside, A. G. (2014). Embrace perform model: Complexity theory, contrarian case analysis, and multiple realities. Journal of Business Research, 67(12), 2495-2503.

Xiang, Z., \& Gretzel, U. (2010). Role of social media in online travel information search. Tourism management, 31(2), 179-188.

Yoo, B., \& Donthu, N. (2001). Developing and validating a multidimensional consumer-based brand equity scale. Journal of Business Research, 52(1), 1-14.

Zhu, F., \& Zhang, X. (2010). Impact of online consumer reviews on sales: The moderating role of product and consumer characteristics. Journal of Marketing, 74(2), 133-148. 